\author{
MACIEJ MYCIELSKI \\ https://orcid.org/0000-0001-5210-0036 \\ Wydział Historii Uniwersytetu Warszawskiego
}

\title{
ZIEMIAŃSKIE DŁUGI A WSPÓLNOTA NARODOWA. SPÓR O MORATORIUM DLA DŁUŻNIKÓW W KRÓLESTWIE POLSKIM W LATACH 1815-1825
}

\begin{abstract}
Abstrakt: Dyskusja o moratorium na spłatę ziemiańskich długów toczyła się w Królestwie Polskim na dwóch sejmach, w 1818 i 1820 r., a także na łamach prasy. Zwolennicy moratorium przedstawiali zadłużenie majątków ziemskich jako efekt ponoszenia wielkich ofiar na cele narodowe i zniszczeń wojennych w czasach Księstwa Warszawskiego. Ofiarnym ziemianom przeciwstawiano egoistycznych posiadaczy kapitałów, chcących przejąć majątki ziemskie. Zwolennicy i przeciwnicy zawieszenia spłaty długów odwoływali się do różnych koncepcji wspólnoty narodowej i do różnych ideałów obywatelstwa, inaczej też przedstawiali polityczną rolę różnych grup społecznych.
\end{abstract}

Słowa kluczowe: sejmy Królestwa Polskiego 1818 i 1820 r.; zadłużenie dóbr ziemskich; wyobrażenia wspólnoty narodowej; myśl konserwatywna.
Abstract: The debate over the moratorium on the repayments of landowners' debts was held in the Kingdom of Poland during two Sejm sessions, in 1818 and 1820, and in the press. The supporters of the moratorium presented the indebtedness of landed estates as the result of heavy sacrifices made by the landed nobility for national purposes and war damage in the period of the Duchy of Warsaw. The image of generous landlords was set against that of egoistic capitalists seeking to take over landed estates. Supporters and opponents of the temporary moratorium on debt payments appealed to different concepts of the national community and ideals of citizenship and differently presented the political role of various social groups.

Keywords: 1818 and 1820 Sejms of the Kingdom of Poland, indebtedness of landed estates, images of the national community, conservative thought. 
Moratorium dla dłużników wprowadzone w czasach Księstwa Warszawskiego oraz dyskusje sejmowe i publicystyczne dotyczące przedłużania jego obowiązywania w latach 1815-1825 były traktowane w dotychczasowych badaniach jako część szerszego zagadnienia - genezy Towarzystwa Kredytowego Ziemskiego (TKZ), powołanego w Królestwie Polskim w 1825 r. ustawą sejmową. Dwie duże debaty w izbie poselskiej o przedłużeniu moratorium (1818 i 1820) oraz dość obfita publicystyka były omawiane łącznie z kolejnymi projektami „systematu kredytowego” czy „banku ziemiańskiego”, aż po ostateczny projekt sejmowy z 1825 r. ${ }^{1}$ Przy czym z punktu widzenia dziejów TKZ sprawa moratorium była raczej drugorzędną kwestią.

Nie przyglądano się natomiast innemu, interesującemu aspektowi dyskusji o moratorium - temu, jak były w niej rozumiane pojęcia „naród”, „państwo” i „obywatelstwo” oraz jak wyobrażano sobie społeczne podstawy wspólnoty politycznej. Paradoksalnie, właśnie debaty o moratorium dla dłużników (zwłaszcza sejmowe ${ }^{2}$ ) dały okazję do jednej z ciekawszych dyskusji na te tematy między 1806 a 1830 r. Wzięło w niej udział kilkadziesiąt osób, zarówno warszawskich urzędników i publicystów, jak i członków izby poselskiej reprezentujących środowiska pozawarszawskie. Ten duży zasięg dyskusji jest szczególnie istotny, pozwala bowiem wyjść poza krąg koncepcji wspólnoty narodowej czy politycznej formułowanych przez znanych intelektualistów i przyjrzeć się wyobrażeniom na ten temat funkcjonującym wśród szerszych środowisk uczestniczących w życiu politycznym. Sądzę, że debaty o moratorium są też ważne dla badań nad dziejami różnych nurtów konserwatywnych w Polsce w pierwszym trzydziestoleciu XIX w.

Praktyczne zawieszenie spłaty długów hipotecznych wprowadzono w czasach Księstwa Warszawskiego kilkoma dekretami króla Fryderyka Augusta, a następnie potwierdzono uchwałą Rządu Tymczasowego Królestwa Polskiego z 23 października 1815 r. ${ }^{3}$ Zostało ono przedłużone postanowieniem Aleksandra I z 16 lipca 1817 r., które ustanawiało

${ }^{1}$ Najważniejsze prace omawiające początki TKZ powstały jeszcze przed $1914 \mathrm{r}$. (F. Czermiński, O Towarzystwie Kredytowym Ziemskim w Królestwie Polskim, Warszawa 1866, s. 1-223; S. Jasiukowicz, Zarys dziejów powstania Towarzystwa Kredytowego Ziemskiego, „Przegląd Narodowy” 4, 1911, 8, s. 121-156; 9, s. 250-284).

2 Istotne są tu dyskusje $\mathrm{w}$ izbie poselskiej. W dyskusji o moratorium w senacie w 1818 r. wystąpiło zaledwie czterech mówców; wszyscy byli przeciwni moratorium, ale deklarowali, że senat powinien jednomyślnie przyjąć projekt. Tak też się stało (Diariusz sejmu Królestwa Polskiego 1818, t. 2, Warszawa 1818 [dalej: Diariusz 1818], s. 45-47). Diariusz posiedzeń senatu z $1820 \mathrm{r}$. nie został opublikowany.

${ }^{3}$ Zob. omówienie tych aktów prawnych w mowie J.K. Szaniawskiego w senacie w 1818 r. (Diariusz 1818, t. 2, s. 42). 
moratorium na spłatę długów hipotecznych trwające do 1 stycznia 1821 r. (a dotyczyło długów zaciągniętych przed 20 czerwca 1815 r.) ${ }^{4}$. Projekt wniesiony w $1818 \mathrm{r}$. pod obrady sejmu był potwierdzeniem tego postanowienia cesarza. Sytuacja legislacyjna była dziwna - jak ironizował w czasie obrad poseł Wincenty Niemojowski - zarówno ci głosujący za projektem, jak i ci przeciw niemu „dosyć rzadkim zaiste zdarzeniem, dzisiaj na jedno się zgodzą"5. Było bowiem jasne, że odrzucenie projektu przez sejm nie spowoduje odwołania postanowienia cesarskiego. Każdy wynik głosowania dawał więc ten sam rezultat: koniec moratorium miał nastąpić 1 stycznia 1821 r. Reprezentujący rząd Józef Kalasanty Szaniawski tłumaczył jednak, że wniesienie projektu oznacza przekazanie przez monarchę sejmowi wszelkich dalszych decyzji w tej materii. Miało to dawać dodatkową gwarancję wierzycielom, że moratorium rzeczywiście skończy się w oznaczonym terminie. Projekt przeszedł 113 głosami przeciw siedmiu ${ }^{6}$. Na sejmie we wrześniu $1820 \mathrm{r}$. przedłużono moratorium o rok - do końca 1821 r., zastrzegając, że w następnych latach wierzyciele będą mogli co roku wypowiedzieć jedną czwartą zahipotekowanego kapitału. Wynik głosowania był znacznie gorszy dla rządu, gdyż projekt przeszedł 66 głosami przeciw $51^{7}$. Wydaje się, że na takim rezultacie głosowania zaważyło poczucie, iż przedłużenie moratorium jest złamaniem zapewnień danych wierzycielom dwa lata wcześniej. Po sejmie $1820 \mathrm{r}$. rozpoczęły się prace nad powołaniem TKZ, zwieńczone prawem uchwalonym na sejmie $1825 \mathrm{r}$. Podczas towarzyszących im dyskusji powracały wątki z wcześniejszych debat nad moratorium ${ }^{8}$.

Dyskusje sejmowe o moratorium przenikały się z publicystycznymi. Szaniawski, wprowadzając projekt o moratorium do izby poselskiej w $1818 \mathrm{r}$., mówił, że biorąc pod uwagę „dość liczne” publikacje, „w obecnej materii wszelkie podobno zarzuty, przyczyny i uwagi są już wyczerpanymi" Z kolei zapis obrad izby poselskiej w 1818 i 1820 r. został opublikowany

4 „Dziennik Praw” [Królestwa Polskiego] 3, 1817, 15, s. 381-388.

${ }^{5}$ W. Niemojowski, Głosy posła kaliskiego na sejmie Królestwa Polskiego 1818, Poznań [b.d.w.], s. 8.

${ }^{6}$ Diariusz 1818, t. 2, s. 5, 22.

${ }^{7}$ Dziennik posiedzeń izby poselskiej w czasie sejmu Królestwa Polskiego w roku 1820 odbytego, t. 1, Warszawa 1820 (dalej: Dziennik 1820), s. 181, 242.

${ }^{8}$ Z kwestiami zadłużenia i „systematu kredytowego" związane były też inne akty prawne uchwalone przez sejm w 1818 r.: prawo hipoteczne, znowelizowane następnie na sejmie 1825 r., oraz prawo o rozgraniczeniu dóbr ziemskich (zob. W. Wójcikiewicz, Prawo hipoteczne Królestwa Polskiego, Wrocław 1967, s. 56-84). Dyskusje nad nimi w sejmie miały jednak rzeczowy charakter, pozbawiony tak rozbudowanych uzasadnień ideowych jak dyskusje o moratorium.

${ }^{9}$ Diariusz 1818, t. 2, s. 3. 
w wydanych współcześnie diariuszach, więc wypowiedzi posłów i deputowanych funkcjonowały w tym samym obiegu co artykuły w czasopismach czy broszury ${ }^{10}$. Dyskusje w izbie poselskiej miały jednak swoją specyfikę. Były one ograniczone przez stan prawny i wniesione projekty, a mówcy nie mogli zanadto odbiegać od materii, pod groźbą upomnienia lub odebrania głosu przez marszałka ${ }^{11}$. W tekstach publicystycznych łatwiej było przedstawiać problem moratorium w szerszym kontekście.

O ile zasady „systematu kredytowego" były skomplikowaną kwestią, a dyskusja o nich wymagała znajomości analogicznych systemów funkcjonujących w innych krajach (odnoszono się głównie do rozwiązań przyjętych w Prusach), o tyle dyskusja o moratorium i jego skutkach była stosunkowo prosta. Projekt prawa o moratorium wniesiony na sejmie w $1818 \mathrm{r}$. składał się z jednego zdania, a analogiczny projekt z $1820 \mathrm{r}$. z trzech zdań ${ }^{12}$. Lakoniczność tych projektów, brak trudnej materii legislacyjnej, pozwalały na bardziej ideologiczny charakter dyskusji.

Sytuacja, która powstała na skutek zadłużenia ziemiaństwa, strat wojennych i długotrwałego moratorium była przedstawiana w publicystyce i w czasie narad sejmowych jako kluczowy problem gospodarczy, a także jako wielki społeczny konflikt. Często opisywano ją jako wojnę wierzycieli z dłużnikami. Józef Wybicki oceniał: „W tych wszystkich, że tak powiem, wyziewach naszej rozpaczy, przyszedł mi na myśl ów okręt, długą burzą skołatany, na którym marynarze, śmiercią głodu zagrożeni, rzucają się wreszcie na siebie i jedni w śmierci drugich życia pokładają nadzieje"13. Moratorium traktowano jako rozejm w tej wojnie. Rząd konstytucyjny - mówił w sejmie 1818 r. radca stanu Szaniawski zastał w 1815 r. ,te dwie, przez przeciąg lat kilku od prawnych zatargów

${ }_{10}$ Oba diariusze były ocenzurowane. W 1818 r. stało się to na polecenie namiestnika Józefa Zajączka; diariusz został skrócony, usunięto ostrzejsze sformułowania (N. Gąsiorowska, Wolność druku w Królestwie Kongresowym 1815-1830, Warszawa 1916, s. 43-44). Wincenty Niemojowski skarżył się, że niektóre jego mowy opuszczono w diariuszu, a inne ,poobcinane i grubymi oszpecone są pomyłkami” (W. Niemojowski, op. cit., s. 5). Generalnie jednak diariusz ten, przynajmniej w założeniu, podawał mowy in extenso. W „dzienniku posiedzeń” izby poselskiej z $1820 \mathrm{r}$. wystąpienia były streszczane, często do kilku zdań. Można przypuszczać, że ofiarą tego streszczania padały często treści, które najbardziej nas tu interesują - szersze opisy sytuacji czy uzasadnienia ideowe.

${ }^{11}$ W 1820 r. marszałek Rajmund Rembieliński po głosie Dominika Krysińskiego zwrócił uwagę izbie, że „chociaż wprowadzony projekt wedle swej natury może mieć styczność ze skarbem publicznym i interesem prywatnych, należy jednakże obradującym poprzestać na ogólnym dotknięciu podobnych materii, nie zaś oddaleniem się od głównego przedmiotu zmieniać cel dyskusji” (Dziennik 1820, t. 1, s. 192-193).

12 Diariusz 1818, t. 2, s. 2; Dziennik 1820, t. 1, s. 181.

${ }^{13}$ J. Wybicki, Listy do Jana Węgleńskiego ministra stanu, „Pamiętnik Warszawski” 7, 1817, marzec, s. 277. 
wstrzymywane strony, miotane na przemian uczuciami zniecierpliwienia, obawy i zwątpienia”. Po zniesieniu moratorium „całe szeregi familiów stanęłyby może między sobą do zapasów prawniczego sporu, a stanęłyby z rozjątrzonym przez długie oczekiwanie uczuciem"14. Spór ten został przedstawiony przez marszałka Wincentego Krasińskiego przy wprowadzeniu projektu do izby poselskiej w $1818 \mathrm{r}$. W przeciwieństwie do innych projektów, które marszałek dość miękko rekomendował izbie, tu poparcie było jednoznaczne i bardzo emocjonalne ${ }^{15}$. Strony sporu zostały bardzo wyraźnie zarysowane. „Majątek krajowy dzieli się na dwie części, pierwszą składają dóbr ziemskich posiadacze, drugą właściciele brzęczącej monety”. Ci drudzy to „kapitaliści”, czyli posiadacze kapitałów. Ziemianie zostali zrujnowani w czasach Księstwa Warszawskiego („wojna, zabory, zniszczenia, rekwizycje i różnogatunkowe podatki"). Kapitaliści „żadnych ciężarów nie znali”, „nienaruszeni w kapitałach i procentach, które hipoteka im zapewniła", a często wzbogacili się na wojnie. A teraz bezwzględnie żądają zwrotu długów ${ }^{16}$. Te wizerunki wierzycieli i dłużników będą rozbudowywane w licznych wystąpieniach na obu sejmach.

Podstawowym tytułem do domagania się moratorium były zniszczenia wojenne i ofiarność ziemian na cele narodowe - „nadzwyczajne ofiary, które ten talizman duszy Polaka, miłość ojczyzny, wycisnął"17. Szaniawski, wnosząc projekt w imieniu rządu do izby poselskiej w 1818 r., przekonywał: „Od dawna już powiedzianym było, że dzieje długów w tym kraju są razem publicznych nieszczęść naszych dziejami"18. Zadłużenie było niekiedy łączone jeszcze z wydarzeniami z XVIII w. Ludwik Łętowski pisał w swojej broszurze z 1816 r., że moratorium potrzebne jest w „nagrodę kilkudziesiątletniego męczeństwa” dla „udręczonego ziemianina"19. Minister skarbu Ksawery Lubecki, wprowadzając w 1825 r. do izby poselskiej projekt o TKZ, rozpoczął ten ciąg narodowych nieszczęść, stanowiących genezę zadłużenia dóbr, jeszcze wcześniej - od najazdu szwedzkiego w połowie XVII w. ${ }^{20}$ Ale przede wszystkim eksponowano

${ }^{14}$ Diariusz 1818, t. 2, s. 3-4.

${ }_{15}$ M. Mycielski, Między izba a cesarzem. Marszałkowie izby poselskiej w Królestwie Polskim, PH 84, 1993, s. 137-138.

16 Diariusz 1818, t. 2, s. 1.

17 Myśli o upadku kredytu krajowego, „Gazeta Korrespondenta Warszawskiego i Zagranicznego" 4 VI 1821, 89, s. 1143.

18 Diariusz 1818, t. 2, s. 2.

19 L. Łętowski, 0 moratorium czyli dwa sposoby uiszczenia się wierzycielom, Warszawa 1816, s. $19-20$.

${ }^{20}$ F.K. Lubecki, Mowa jaśnie oświeconego księcia ... ministra przychodów i skarbu, miana w izbie poselskiej na posiedzeniu dnia 21 maja 1825 roku przy wniesieniu projektu do prawa o Towarzystwie Kredytowym Ziemskim, [b.r.m.w.]. 
okres Księstwa Warszawskiego jako czas „klęski narodowej” z powodu zniszczeń wojennych ${ }^{21}$. Wielu uczestników dyskusji w izbie poselskiej prześcigało się w opisach tej klęski. Poseł Ignacy Komorowski przekonywał: ,jedna tylko i wyłączna część mieszkańców, to jest posiadaczów ziemi i nieruchomości, doznała całego ogromu biedy, klęsk, nieszczęść, nędzy i zniszczenia”22. A poseł Dawid Oebschelwitz wołał: „Kto z was był tak szczęśliwym uchronić się okropności nieoddzielnie wojnom towarzyszących? Czy nie wy właściciele ziemi cały jej ciężar dźwignęli? A pod jej uciskiem upadli?"23. Inni dyskutanci, jak wprowadzający do debaty w 1818 r. marszałek Krasiński, kładli raczej nacisk na dobrowolne ofiary ziemian dla ojczyzny w czasach Księstwa, mówiąc o ich „zupełnym oddaniu się ojczyźnie” i „usługach poświęconych dobru narodu”24. Podkreślano ofiary pieniężne, wystawianie własnym kosztem wojska, a także ochotniczą służbę w tym wojsku ${ }^{25}$. To właściciele ziemscy przez swoją ofiarność mieli zapewnić odrodzenie ojczyzny. Krasiński w 1820 r. mówił o przyszłości kraju „majątkiem i ofiarą licznych familii i właścicieli ziemiańskich podźwignionego" ${ }^{26}$. Onufry Małachowski stwierdzał: „Duch szlachetności narodowej, ten duch cenny i szanowny w Polaku, któraż klasa zaszczytniej utrzymywała, jeżeli nie obywateli ziemianów”. Przy czym „szlachetność” to, jak wynika z kontekstu, przede wszystkim ofiarnośćc ${ }^{27}$. Ziemiańskie ofiary, przekonywał poseł Jan Mikorski, „zjednały nam szacunek u wszystkich mocarstw Europy"28.

Ziemianie wywalczyli ojczyznę również dla kapitalistów. Krasiński mówił o tych drugich: „Zapomnieli równie, że z krajowego zniszczenia swe majątki całkowicie wzniosłszy, częstokroć je podwoiwszy, nic nie poświęcili i do ojczystego bytu nic się nie przyczynili, a jednak równie z innymi mają prawo chełpić się Polaka imieniem"29. Z kolei poseł Franciszek Obniski pytał, czy ziemianie mają się stać ofiarą kapitalistów, „dla których, równie jak dla siebie drogie imię, byt i ojczyznę troskliwie zabezpieczaliście"30. Nikt nie negował, że kapitaliści są pełnoprawnymi obywatelami i Polakami. Ale ten status został im niejako ofiarowany

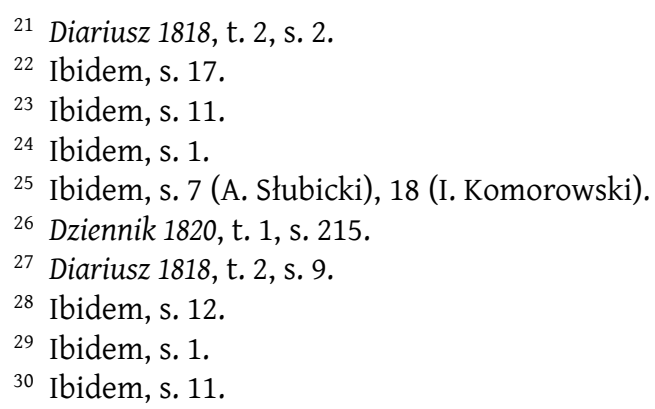


przez tych, którzy walczyli o narodowy byt. Poczucie nierównego zaangażowania w wysiłek zbrojny czasów Księstwa Warszawskiego i tego, że „pogrom ojczysty”31, jak to nazwał Krasiński, dotknął głównie ziemiaństwo, wiązało się chęcią wyrównania bilansu strat i ofiar. Poseł Stanisław Pieniążek zestawiał ze sobą ziemianina i kapitalistę, dodając: „Rząd, ojczyzna na szali sprawiedliwości ważąc nas obu, zobaczymy, kogo użyteczniejszym obywatelem osądzi i który z nas lepiej jej się zasłużył" 32 . Łętowski w opublikowanej w 1816 r. broszurze pytał, dlaczego to jedynie właściciele ziemi mają ponosić skutki ciężkich czasów: „lecz czyliż ciężar nieszczęść spadnie na samego rolnika; po pół wieku usiłowań, ofiar i obawy, czyliż jeszcze z torbą z dziedziny ojców wygnanym zostanie". I wprost postulował, by kapitalistów uczynić „uczestnikami powszechnej klęski narodowej"33.

Kapitaliści, zdaniem zwolenników moratorium, żadnych ofiar nie ponieśli. Onufry Małachowski przedstawiał w czasie dyskusji sejmowej w 1818 r. „uciski ziemianina, obok rozkosznej doli kapitalisty” w czasach Księstwa Warszawskiego ${ }^{34}$. Oskarżano kapitalistów o zarabianie na wojnie. Byli to - mówił w 1820 r. szczególnie mocno akcentujący ten wątek marszałek izby poselskiej Rajmund Rembieliński - spekulanci, „którzy siodła robili, co chleb dla wojsk wypiekali, co im za drogą cenę dostarczali furażów"35. Oczywiście chodzi tu o osoby organizujące dostawy, a nie wytwarzające towary potrzebne wojsku. Ale częściej ukazywano kapitalistów jako zastygłych w bezruchu podczas wojen, czekających na lepsze czasy. Odzywało się tu charakterystyczne dla publicystyki czasów Księstwa Warszawskiego potępienie nieangażujących się w zbiorowy wysiłek patriotyczny egoistów, zrównywanie takiej postawy ze zdradą narodową ${ }^{36}$. „Kapitaliści siedzący w miastach [--] spokojnie wyglądają z swych kantorów na klęski wszystkich innych klas współobywateli" pisano $\mathrm{w}$ artykule prasowym ${ }^{37}$. Autor innego artykułu pisał o kapitalistach, „z których żaden nie słyszałem, aby się bił kiedy z nieprzyjacielem, albo przynajmniej dał zastępcę; nie tylko nie dzielił strat z ziemianinem,

31 Ibidem, s. 1.

32 Ibidem, s. 20.

33 L. Łętowski, O moratorium, s. 15, 28.

34 Diariusz 1818, t. 2, s. 10.

${ }^{35}$ Dziennik 1820, t. 1, s. 239. Zob. też s. 208.

36 Zob. J. Czubaty, Zasada „dwóch sumień”. Normy postępowania i granice kompromisu politycznego Polaków w sytuacjach wyboru (1795-1815), Warszawa 2005, s. 389.

37 J.K, Uwagi nad kapitalistami i szkodliwymi skutkami lichwy, „Rozmaitości Warszawskie” (dodatek do „Gazety Korrespondenta Warszawskiego i Zagranicznego”), 11 V 1825, 19, s. 149. 
subiekcji nawet kwaterunkowej nie znał, gdy obywatel osiadły zaledwie czasem z żoną i dziećmi miał się czym posilić, gdzie i na czym położyć, kapitalista najadłszy się, wyspawszy spokojnie, rachował sobie procenta, które mu co dzień rosły”38. „Kapitalista obojętny na obecność [czyli teraźniejszość - M.M.], w nieczynnym zaufaniu, śpi wśród zniszczenia, budzi się z pomyślnością" - oceniał deputowany ksiądz Łętowski ${ }^{39}$. Kapitalista budzi się w spokojniejszych czasach, by zaatakować ziemianina. Onufry Małachowski mówił w 1818 r., że kapitalista „czyha z natężoną chciwością na tę zgubną chwilę, aby mieczem ostrości prawa przeciął wątek rozwijać się poczynającej swobody zniszczonego i mozolnie pracującego ziemianina" ${ }^{0}$. W 1818 r. Krasiński przewidywał, że „ta część obywateli, co w naszych ofiarach udziału nie miała, co na zwaliskach odwiecznych majątków się podniosła, rozdrażniona zatrzymaniem w chyżym biegu swych spekulacji, rzuci się raptem na ziemne posiadłości"41.

W obrazie kapitalistów odzywało się kilka stereotypów. Ważne było przeciwstawienie ludzi osiadłych i nieosiadłych. Kapitalistów, wywodził ksiądz Łętowski, „ruchomość ich dobytku, czyni obywatelami całego świata; skacząc po kraju, dybią na dogodne wydarzenia; nie ma korzyści, której by sobie nie przywłaszczyli, z samego nieszczęścia więcej niż obronną ręką wychodząc"42. Kapitaliści to nowa magnateria. Stanisław Kostka Potocki pisał o "możnowładcach pieniężnych i przemysłowych" i o „potężnej pieniężnych klice”, o tym, że jeśli „rząd nie obmyśli pewnych środków, wnet i szczątki obywatelskich majątków przejdą w ręce tych brodatych i niebrodatych możnowładców" ${ }^{43}$. Wizerunek nieczułych na nieszczęścia współobywateli „kapitalistów na kufrach żelaznych siedzących" ${ }^{4}$, ludzi, z których nikt nie ma żadnego pożytku, wydaje się też odwołaniem do funkcjonującego w kulturze archetypu skąpca.

Pojawiało się w tych dyskusjach charakterystyczne operowanie pojęciami większej i mniejszej części narodu. Anonimowy publicysta pisał: „trzy części zasłużonych ojczyźnie obywateli, znoszących wszystkie ciężary wojny, miałyby być zaledwie od 4tej części samolubców z swych

38 Odpowiedź na uwagi względem upadku kredytu i onegoż polepszenia, „Gazeta Korrespondenta Warszawskiego i Zagranicznego" 15 VI 1821, 95, s. 1198.

39 L. Łętowski, O moratorium, s. 28.

40 Diariusz 1818, t. 2, s. 9.

${ }^{41}$ Ibidem, s. 1. Podobnie Krasiński mówił podczas sejmu 1820 r. (Dziennik 1820, t. 1, S. 215).

${ }^{42}$ L. Łętowski, O moratorium, s. 14.

${ }^{43}$ S.K. Potocki, Świstek krytyczny, „Pamiętnik Warszawski” 7, 1817, luty, s. 259-260.

${ }^{44} \mathrm{~J}$. Wybicki, Listy obywatelskie do Jana Węgleńskiego ministra stanu, „Pamiętnik Warszawski" 6, 1816, listopad, s. 276. 
majątków obdarte"45. Poseł Komorowski uważał w 1818 r. za niedopuszczalne, aby „liczniejsza część narodu posiadaczów ziemi, która dawszy tyle dowodów patriotyzmu sama tylko nieodzowną podporą wskrzeszonego tronu być może, miała być poświęcona mniejszej części narodu, która z kapitałów swoich do żadnych potrzeb ojczyzny nie przykładała się"46. Bonawentura Niemojowski, popierając moratorium, mówił w 1820 r., że „dla zaratowania większości narodu, rygor stałych praw złagodzić można"47. Radca stanu Kajetan Kalinowski tłumaczył zaś w 1820 r., że zniesienie moratorium ,jest przy tak znacznej liczbie dłużników wielką ruiną obywateli, zatym większej części narodu"48. Większość narodu to zatem właściciele ziemscy, a mniejszość to posiadacze kapitału. Mamy tu więc obraz narodu złożonego ze szlachty i zamożniejszych mieszczan, tak, jak w koncepcjach z czasów Sejmu Czteroletniego. Słowo „obywatel” było w dyskusjach o moratorium raz zastrzeżone dla właścicieli ziemskich, innym razem rozciągane również na „kapitalistów”. Na pewno nie było jednak używane w znaczeniu przyjętym w ustawodawstwie Królestwa Polskiego, gdzie oznaczało prawo do sprawowania urzędów publicznych ${ }^{49}$.

Dla przeciwników moratorium wizja ziemian zadłużających się na ratowanie ojczyzny i egoistycznych kapitalistów czyhających na ich majątki była wielką mistyfikacją. Starali się oni deheroizować dłużników. Celował w tym szczególnie znany prawnik Ignacy Stawiarski, autor wydanej w 1816 r. broszury o moratorium. „Ci, którzy głos za moratorium podnoszą - pisał - całą swoją siłę na tym opierają, że Polak musiał się zadłużyć na powstanie narodu. [--] przywdziawszy tych dłużników w płaszcz patriotyzmu, w tej masce chcą dla nich pod hasłem miłości ojczyzny pozyskać przywilej na zagrabienie własności cudzej"50. Uważał, że nie ma podstaw, by wiązać zadłużenie z zasługami patriotycznymi. Nierzetelnego dłużnika nie można nazwać patriotą, „patriotyzm bowiem jest najwyższą cnotą, a zatem jest zbiorem wszystkich cnót prywatnych". Nie jest patriotą, kto „chce wady i szkodliwe przesądy, sobie, lub komu dogodne pod narodowość podciągnąć" ${ }^{1}$. Jeśli ktoś nawet zadłużył się

45 Odpowiedź na uwagi względem upadku kredytu i onegoż polepszenia, „Gazeta Korrespondenta Warszawskiego i Zagranicznego" 16 VI 1821, 96, s. 1212.

${ }^{46}$ Diariusz 1818, t. 2, s. 18.

${ }^{47}$ Dziennik 1820, t. 1, s. 202, 207.

48 Ibidem, s. 221.

49 M. Mycielski, Rząd Królestwa Polskiego wobec sejmików i zgromadzeń gminnych 18151830, Warszawa 2010, s. 24-25.

50 [I. Stawiarski], Uwagi nad moratorium, Warszawa 1816, s. 15.

51 Ibidem, s. 18-19. Podobnie autor prasowej recenzji broszury Łętowskiego o moratorium uważał, że zwolennicy moratorium chcą „pięknymi wyrazami narodowości, 
„dla heroizmu jakiego" nie oznacza to, że może nie oddawać długu ${ }^{52}$. Ale Stawiarski uważał patriotyczną genezę zadłużenia za fikcję - wskazywał, że długi nie pochodzą wcale z czasów Księstwa Warszawskiego. W rzeczywistości zostały one zaciągnięte przed 1806 r. i to przy bardzo dobrej koniunkturze w rolnictwie; były zatem efektem nieudolności, marnotrawstwa lub spekulacji ${ }^{53}$. Ten argument o pochodzeniu długów z czasów pruskich będzie zresztą wielokrotnie powracał w sporze o moratorium. Jeśli ktoś ucierpiał w czasie wojen napoleońskich, przekonywał Stawiarski, to raczej ziemianie wierzyciele, a więc ci dobrze prosperujący, bo „rekwizycja u nich żywność zastała i zabrała”. Co więcej - musieli dać za siebie i za swoich dłużników, którym nie było co zabieraćs ${ }^{54}$. Innym sposobem deheroizacji dłużników było wskazywanie, że zadłużenie wynika z importu luksusowych towarów. Poseł Józef Grabowski twierdził w 1818 r., że długi zostały zaciągnięte na ,zbytki, to jest kosztowne szale, konie anglizowane, portery, fajanse i kapelusze z piórami" 55 . Wybicki, pisząc o moratorium, narzekał, że „zepsute obyczaje, bezwstydne marnotrawstwo, oko skromne rażące zbytki rozlały się jak lawa wszystko pożerająca po naszym wielkim ziemiaństwie" ${ }^{56}$. W podobnym duchu deputowany ksiądz Jan Jakubowski radził w 1820 r., by zamiast projektu moratorium przyjąć zakaz importu przedmiotów zbytku ${ }^{57}$.

Jak przeciwnicy moratorium odpowiadali na obraz drapieżnych wierzycieli - kapitalistów? Pierwsza możliwą odpowiedzią była pochwała kapitalisty. Dominik Krysiński mówił:

Skądże ta wzgarda, tyle razy w tej izbie, na tych rzucona, których kapitalistami nazywamy? Szanujmy ich, szanujmy kapitały, bo inaczej Polska bolesne zawsze wystawiać będzie porównanie z tymi narodami, u których

patriotyzmu, obrony ziemianina i stanu rolniczego przykryć swój interes i za tą tarczą bronić go zapalczywie" (O moratorium, czyli dwa sposoby uiszczenia się wierzycielom, Warszawa 1816 [rec.], „Pamiętnik Warszawski” 7, 1817, styczeń, s. 104).

52 [I. Stawiarski], op. cit., s. 15.

53 Ibidem, s. 15-18.

${ }^{54}$ Ibidem, s. 20.

${ }^{55} \mathrm{~J}$. Grabowski, Głos jaśnie wielmożnego ... posła województwa podlaskiego z powiatu węgrowskiego miany na sesji sejmowej dnia 12 kwietnia 1818 roku, [b.m.r.]. Fragmentu tego nie ma w mowie drukowanej w diariuszu (Diariusz 1818, t. 2, s. 16-17).

${ }^{56}$ J. Wybicki, Listy obywatelskie do Jana Węgleńskiego ministra Król. Polsk., „Pamiętnik Warszawski” 6, 1816, październik, s. 166. Wybicki był zdecydowanym przeciwnikiem moratorium. W 1818 r. mówił w senacie o „szkodliwej zarazie moratoryjnej” (Diariusz 1818 , t. 2, s. 46).

${ }^{57}$ Dziennik 1820, t. 1, s. 232-233; podobnie mówił w 1818 r. poseł Stanisław Jeziorkowski (Diariusz 1818, t. 2, s. 17). 
i kapitały, i kapitaliści największej od prawa doznają opieki. [--] Nazywano magazynierami, lichwiarzami, egoistami tych, którzy przez swoją oszczędność przy ciągłym dążeniu do pomnożenia masy kapitałów są istotnymi dobroczyńcami i jedyną podporą narodowego przemysłu ${ }^{58}$.

Ale to odosobnione podejście. Bo przede wszystkim stawiano pytanie, czy kapitaliści w ogóle w Polsce istnieją. Stronnicy moratorium, pisał Stawiarski, dają wierzycielom „pyszny tytuł kapitalistów”. W rzeczywistości w „naszym ziemiańskim, rolniczym kraju nie jest znana klasa kapitalistów, jaka się w obcych narodach znajduje". Nie ma banków, a bankructwa bankierów warszawskich w końcu XVIII w. „dały pamiętną każdemu Polakowi naukę, że się nigdy nie odważy być kapitalistą w swoim kraju”59. Anonimowy autor pisał w 1817 r. w „Pamiętniku Warszawskim”: „Prawi u nas wielu o kapitalistach, lubo w istocie nie mamy ich wcale, mianowicie i takich, o jakich w krajach zagranicznych ekonomia polityczna mówi" 60 . Podobnie twierdził Stanisław Staszic w czasie prac legislacyjnych w Radzie Stanu nad projektem o „banku ziemiańskim” w 1816 r. Wierzyciele, mówił, są przedstawiani na wzór sytuacji w Anglii, gdzie istnieje duża grupa osób żyjących z kapitałów ulokowanych w bankach. Natomiast w warunkach polskich i dłużnicy, i wierzyciele to przede wszystkim ziemianie, często są to zresztą te same osoby ${ }^{61}$.

Przeciwnicy moratorium wskazywali, że większość zadłużenia to tak naprawdę rozliczenia między posiadaczami ziemskimi oraz że wielu wierzycieli jest równocześnie dłużnikami. Podawali przykłady ziemian, którzy nie mogąc odebrać pożyczki, sami musieli się zadłużać, oraz wdów i sierot, które nie mogły odebrać zahipotekowanych sum ${ }^{62}$. Według Stawiarskiego wierzyciele to dobrze gospodarujący właściciele ziemscy, dzierżawcy lokujący kapitały u zamożnych ziemian, wspomniane już wdowy i sieroty, wreszcie instytucje kościelne i szpitale ${ }^{63}$. Opisywał on kobietę, która pozbawiona posagu musi pozostać w staropanieństwie, „a może biedna! uwiedziona i rozpuście odda się”, młodzieńca, który, „nie mogąc użyć swojej zagrabionej własności”, nie ma warunków do rozwijania swoich talentów, oraz człowieka, który nie może zainwestować pieniędzy w śmiałe przedsięwzięcia gospodarcze. Na skutek moratorium

58 Diariusz 1818, t. 2, s. 14.

59 [I. Stawiarski], op. cit., s. 21-22.

${ }^{60}$ O moratorium, czyli dwa sposoby, s. 104.

${ }^{61}$ M. Usurski, Udział Stanisława Staszica w pracach Rady Stanu Królestwa Polskiego, „Zeszyty Staszicowskie" 2006, 5, s. 106.

${ }^{62}$ Diariusz 1818, t. 2, s. 16 (J. Grabowski); Dziennik 1820, t. 1, s. 210-211 (A. Łabęcki).

${ }^{63}$ [I. Stawiarski], op. cit., s. 22-23. 
„wszystkie te istoty muszą pozostać martwe, nieczynne i moralnie cierpiące na to, że nie mogą być sobie i krajowi użyteczne". A co gorsza, próżnując i mając poczucie krzywdy, będą ulegały demoralizacji ${ }^{64}$. Zwracano uwagę, że właśnie żyjące z „procencików” wdowy i sieroty znalazły się w najgorszej sytuacji „przez ciąg burzliwej epoki”65.

To, co przeciwnicy moratorium pisali i mówili o dłużnikach i wierzycielach (zwłaszcza o zadłużeniu z czasów pruskich) było na pewno znacznie bliższe rzeczywistości społecznej i gospodarczej niż twierdzenia ich adwersarzy dominujących w izbie poselskiej. Czy mamy zatem do czynienia ze zwykłą demagogią większości sejmowej, ze świadomym konstruowaniem fikcyjnej rzeczywistości? Czy przeważający w tych dyskusjach obraz społeczeństwa był zbiorowo wytworzony na potrzeby obrony interesów dłużników? Rzecz jest bardziej złożona. Sejmowa dyskusja o moratorium odzwierciedlała lęk przed nagłą zmianą społeczną, przed zachwianiem pozycji gospodarczej i społecznej ziemiaństwa, przed wymianą elit, lęk, który w środowisku ziemiańskim pojawił się czasach Księstwa Warszawskiego. Wynikał on w dużym stopniu z nowego kształtu państwa z jego profesjonalnym aparatem urzędniczym i sądowniczym oraz z nowej rzeczywistości prawnej po wprowadzeniu Kodeksu Napoleona. Istotne były też obawy ziemian związane ze zniesieniem poddaństwa chłopów. Pojawiały się katastroficzne wizje upadku dotychczasowych właścicieli ziemskich, którzy mieli zostać zastąpieni przez wzbogaconych prawników, urzędników czy finansowych spekulantów. Nawet jeśli w rzeczywistości były to rzadkie sytuacje, to tak wyobrażano sobie długofalowe skutki obserwowanych tendencji. Liweranci, „kapitaliści”, obrotni prawnicy wydawali się produktem pewnego systemu i należało się spodziewać, że będą odgrywać coraz większą rolę. Te lęki były w naturalny sposób splecione z problemem zadłużenia ziemiaństwa i z wizją nagłej katastrofy, która nastąpi po zniesieniu moratorium ${ }^{66}$.

Jego zwolennicy musieli sobie poradzić z dwoma zarzutami, dotykającymi podstawowych wymiarów funkcjonowania wspólnoty politycznej. Pierwszy to sprzeczność moratorium, naruszającego prawo własności,

64 Ibidem, s. 27.

${ }^{65}$ Czy sa i jakie sposoby ratowania naszych dłużników, „Rozmaitości” nr 31 (dodatek do „Gazety Korrespondenta Warszawskiego i Zagranicznego”) 30 IX 1820, 130, s. 117.

66 Z. Stankiewicz, Szlachta-ziemianie w świetle ankiety włościańskiej 1814 r., w: Ziemiaństwo polskie 1795-1945. Zbiór prac o dziejach warstwy i ludzi, red. J. Leskiewiczowa, Warszawa 1985, s. 85-120; J. Czubaty, Księstwo Warszawskie (1807-1815), Warszawa 2011, s. 319-469; M. Mycielski, „Miasto ma mieszkańców, wieś obywateli”. Kajetana Koźmiana koncepcje wspólnoty politycznej (do 1830 roku), Toruń 2017, s. 52-144. 
z elementarną sprawiedliwością. Przeciwnicy przywoływali tu cnotliwych szlacheckich przodków. „Marzenia moratoryjne - pisał Stawiarski - nigdy, ani w myśli przodków naszych nie snuły się, ani się w ich sercach nie zagnieżdżały" ${ }^{67}$. Wynikało to z podstawowej cechy charakteru narodowego: „Tak to przodkowie nasi kochali sprawiedliwość! W tym ich była narodowość!”68. Deputowany Filip Kołdowski zauważał, że „dawne wieki nie znały podobnego prawa, chociaż ojcowie nasi więcej może przez wojny i napady niż my ucierpieli" ${ }^{69}$. Poseł Józef Grabowski przekonywał: „hasłem sejmujących przodków waszych nie były inne zaradcze środki, ale ta zasada: pereat mundus, fiat iustitia"70. Zwracano też uwagę na sprzeczność moratorium z konstytucją. Nad tego typu argumentami jego zwolennicy przechodzili do porządku dziennego, uznając, że zaistniał tu stan wyższej konieczności. Takie podejście dobrze oddaje wypowiedź posła Jana Nepomucena Wolickiego, którą tak streszczono w diariuszu sejmu 1818 r.: ,jakkolwiek projekt ten karcie konstytucyjnej przeciwnym być uważał, w teraźniejszym jednak położeniu kraju przyjęcie onego radził". Kilka innych wypowiedzi w 1818 r. miało podobny wydźwięk ${ }^{71}$. Znamienna była postawa przywódców opozycji, braci Niemojowskich. Tak bardzo zwracający uwagę na przestrzeganie konstytucji, postrzegani jako dogmatyczni legaliści, w tej sprawie, popierając moratorium, bardzo lekko podchodzili do konstytucyjnej ochrony własności. Wincenty przywoływał w 1820 r. maksymę: „potrzeba łamie prawo”, a Bonawentura wywodził: „są okoliczności, w których od ogólnych prawideł odstąpić i dla dobra publicznego, dla zaratowania większości narodu, rygor stałych praw złagodzić można"72. W $1818 \mathrm{r}$. pierwszy z nich posłużył się znamienną alegorią: „Gdyby na tonącym promie dwoma stami obciążonym ludzi, pięć osób z brzegu stojących zrzucono w wodę i tym sposobem uratowano resztę, któżby temu poświęceniu kilku nieszczęśliwych przyganiał ofiar"73.

67 [I. Stawiarski], op. cit., s. 28.

${ }^{68}$ Ibidem, s. 14.

${ }^{69}$ Dziennik 1820, t. 1, s. 229. Stawiarski zwracał uwagę, że „były czasy daleko krytyczniejsze od tych, których świeżo doznaliśmy", jak okres panowania Jana Kazimierza, a nie ustanowiono wówczas moratorium ([I. Stawiarski], op. cit., s. 14).

70 Diariusz 1818, t. 2, s. 17.

${ }^{71}$ Ibidem, s. 6 (A. Słubicki), 11 (D. Oebschelwitz), 14 (J.N. Wolicki), 19 (S. Pieniążek).

72 Dziennik 1820, t. 1, s. 202, 207.

${ }^{73}$ Diariusz 1818, t. 2, s. 8. Sens tej alegorii można było zresztą odwrócić. Deputowany ksiądz Konstanty Plejewski, argumentując przeciw moratorium, mówił, że choć dłużnicy zasługują na pomoc, to „ze względu jednak na upadły kredyt, tak by postąpić należało jak ów żeglarz, co gwałtownością burzy na morzu miotany, ażeby siebie i resztę od zguby zachował, najdroższe rzeczy z okrętu wyrzuca" (Dziennik 1820, t. 1, s. 236). 
Drugim zasadniczym zarzutem podnoszonym przez przeciwników moratorium było to, że powoduje ono stagnację gospodarczą i utrwala stan zacofania. Ta „kredytobójcza ustawa”, mówił poseł Michał Potocki w 1820 r., ,zniża kredyt krajowy, wyprowadza kapitały za granicę lub je w kraju czyni martwymi”74. Dominik Krysiński przekonywał: „Kapitały są duszą narodowego bogactwa, Naród, który je zgromadzać, zabezpieczać i szanować umie, w każdym względzie wznieść się potrafi. Przeciwnie w ciągłym zostanie dzieciństwie, ciągle obraz upokarzającej niskości okazywać będzie, gdy nie tylko nic dla utworzenia i pomnożenia kapitałów nie zrobi, lecz nadto na nie targnąć się poważy"75. Poseł Stanisław Jezierski mówił, że moratorium „zatamuje obieg pieniędzy w kraju, któren w ekonomii politycznej jest duszą i życiem w społeczeństwie"76. Stagnacja była tu głównie przedstawiana w kontekście kredytu i obiegu pieniężnego, ale w tle było oczywiście poczucie dramatycznego zacofania gospodarczego. Widoczne jest, że argumentacja ekonomiczna była bardziej kłopotliwa dla ziemiańskich członków izby niż kwestia konstytucyjności moratorium, dotykała bowiem powszechnie przyswojonych i uznanych za oczywiste praw ekonomii. Część zwolenników moratorium była gotowa się zgodzić, że jego utrzymywanie prowadzi do stagnacji. I tak poseł Augustyn Słubicki twierdził, że moratorium ,tamuje bieg cyrkulacji pieniędzy, zrywa handel krajowy, jest przyczyną do zniesienia kredytu pomiędzy prywatnymi i rządem", po czym gładko przechodził do opisu strat i ofiarności ziemian, zestawionej z komfortową sytuacją wierzycieli i kończył poparciem projektu ${ }^{77}$. Podobnie przemawiał poseł Oebschelwitz, który popierał moratorium, uważając równocześnie, że wywołana przez nie sytuacja powszechnego braku zaufania „sparaliżowała wszystkie gałęzie przemysłu narodowego"78. W innych głosach widoczny jest ten sam schemat: przyznanie, że moratorium ma fatalne skutki ekonomiczne, a potem uznanie, że jest nieodzowne ${ }^{79}$.

Znamienne, że ani razu w obu debatach sejmowych nie pada słowo „szlachta”. Widoczna jest wyraźna niechęć do posługiwania się kategoriami stanowymi, które uczestnikom tej dyskusji musiały się wydawać

${ }^{74}$ Dziennik 1820, t. 1, s. 184-185.

${ }^{75}$ Diariusz 1818, t. 2, s. 14.

${ }^{76}$ Dziennik 1820, t. 1, s. 194. Podobnie T. Łubieński (ibidem, s. 197) i S.B. Linde (ibidem, s. 220).

77 Diariusz 1818, t. 2, s. 6-7.

78 Ibidem, s. 10.

79 Ibidem, s. 12 (J. Mikorski), 13 (A. Baliński), 17 (I. Komorowski), 20 (S. Pieniążek); Dziennik 1820, t. 1, s. 201-202 (M. Okołowicz), 213-214 (L. Łętowski), 228-229 (I. Komorowski). 
anachroniczne. Pewnie powodem było i to, że szlachectwo często było w tym okresie przedmiotem satyry, przedstawiane jako instytucja martwa, ,powaga wsparta na pergaminach zbutwiałych”, funkcjonująca już tylko w wymiarze żałosnych pozorów ${ }^{80}$. Anonimowy autor argumentował w 1821 r., że utrata dóbr uwalnia zadłużonych właścicieli od beznadziejnej sytuacji. Tradycja redukowana tu była do śmiesznych ambicji: „Cóż stąd obywatelowi za korzyść, iż herb antenata złocony błyszczy się na bramie pałacu i cyfry naddziadów jego na wazach i srebrze stołowym, które czynny komornik zabiera po skończonym obiedzie ze stołu?"81.

Ziemianie to w tych dyskusjach „dóbr ziemskich posiadacze”, „właściciele ziemi”, „posiadacze ziemi”, „, właściciele ziemiańscy”, „obywatele ziemianie”, „właściciele gruntowi"82. Posiadanie ziemi nie było jednak opisywane w kategoriach czysto ekonomicznych. Szaniawski mówił, że pozbawienie ziemian majątków wystawi kraj na „smutną przemianę co do pierwotnych nawet ogniw narodowości naszej"83. Dobra ziemskie, wywodził Krasiński, „świetnych usług krajowi oddanych lub tylowiecznej pracy były skutkiem i nagrodą"; są to „odwieczne majątki”, a ziemianie to „starodawni ich posiadacze” i „odwiecznych obrońców kraju potomki”" ${ }^{4}$. Onufry Małachowski mówił o majątku „z przodków mu [ziemianinowi] należnym lub krwawo zapracowanym", o mieszkaniu w „odwiecznej dziadów naszych zagrodzie”85. Poseł Jan Raczyński przekonywał, że właściciele ziemscy to „obywatele, których przodki lub oni sami krwią własną drogiej bronili ojczyzny" ${ }^{\prime 6}$. Marszałek Rembieliński

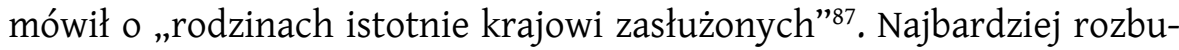
dował ten wątek przywódca opozycji Wincenty Niemojowski, dając

80 Nowy słownik, „Pszczółka Krakowska” 12 XII 1819, 18, s. 200. Zob. A. Zieliński, Naród i narodowość w polskiej literaturze i publicystyce lat 1815-1831, Wrocław 1969, s. 76-86.

${ }^{81}$ J.K., Uwagi nad upadkiem kredytu w kraju i nad środkami zapobiegajacymi niedostatkowi w nim pieniędzy, „Gazeta Korrespondenta Warszawskiego i Zagranicznego” 22 V 1821, 82, s. 1040.

82 Diariusz 1818, t. 2, s. 1, 4, 9, 14; Dziennik 1820, t. 1, s. 177, 187, 198, 215-216, 223, 238.

83 Diariusz 1818, t. 2, s. 4. W przypadku Szaniawskiego za takimi stwierdzeniami stały znacznie szersze konserwatywne koncepcje, formułowane zwłaszcza w jego tekstach z lat 1814-1815 (M. Król, Konserwatyści a niepodległość. Studia nad polska myślą konserwatywna XIX wieku, Warszawa 1985, s. 18-30; T. Kizwalter, O nowoczesności narodu. Przypadek polski, Warszawa 1999, s. 188-190). Szaniawski pisał wówczas, że „państwo każde zachowywać się powinno tymi samymi środkami i maksymami, którymi powstało, wyrosło i kwitnęło" (cyt. za: M. Król, op. cit., s. 20).

${ }^{84}$ Diariusz 1818, t. 2, s. 1-2.

${ }^{85}$ Ibidem, s. 9-10.

86 Ibidem, s. 12.

${ }^{87}$ Dziennik 1820, t. 1, s. 208. 
obraz tysiąca nieszczęsnych rodzin, co w skutek zniesionego nagle moratorium, wypędzone z odwiecznych gniazd swoich, opuszczają w rozpaczy odziedziczone po ojcach włości, owoc prac i trudów, a częstokroć wojennych znojów cnotliwych naddziadów, których zasmucone cienie z zgrozą spoglądają, jak ich niefortunny potomek drżącą ręką chwyta kij pielgrzymski, ustępując miejsca spekulatorom, lichwiarzom, liwerantom, magazynierom łupami naszymi zbogaconym ${ }^{88}$.

Tak więc majątki ziemiańskie to spuścizna walecznych „naddziadów”. Rycerscy przodkowie, odradzający się w swoich potomkach, to zresztą ważny wątek ówczesnego piśmiennictwa. Nieprzypadkowo też w sztuce czasów Księstwa Warszawskiego mamy powtarzający się motyw dawnego Polaka, rycerza w pełnej zbroi wychodzącego z grobu ${ }^{89}$. Ta rycerskość nie musiała być zresztą odczuwana jako prosta kontynuacja świata ojców i dziadów, nie była kwestią zwykłego odruchu tradycjonalistycznego. Rycerz wstający z grobu to raczej „naddziad” niż dziadek, świat rycerski odradza się po dłuższej przerwie, jest odtworzeniem zerwanej wraz ze śmiercią Jana III Sobieskiego prawdziwej egzystencji narodowej.

W debatach o moratorium współcześni ziemianie przedstawiani są jako odtwarzający bohaterskie czyny „naddziadów”, a łącznikiem między pokoleniami są odwieczne siedziby zasłużonych rodzin. Obywatelstwo jest dziedziczone wraz z majątkami, które są gwarancją przetrwania prawdziwych cnót obywatelskich, a także dają możliwość składania ofiar na cele publiczne. Siedziby te ulegają swoistej sakralizacji, gdyż związane są z pierwszą zasadą wspólnoty narodowej, z jej ciągłym odtwarzaniem się za sprawą „rycerzy”. Majątkowy upadek rodzin ziemiańskich musi przerwać ten ciąg bohaterskich czynów i obywatelskich poświęceń. A nowi „możnowładcy” tych tradycji nie mają; zresztą w momencie próby dowiedli swojej obojętności dla sprawy narodowej. Mamy tu więc klasyczną strukturę mitu, z cyklicznym powtarzaniem rytuałów, podtrzymujących istnienie i ład świata (w tym przypadku istnienie narodu). I z poczuciem uczestnictwa w łańcuchu pokoleń powtarzającym te rytuały od niepamiętnych czasów, może od samych początków wspólnoty. Mitu, który miał być punktem odniesienia dla współczesnych, pozwalając zobaczyć, w jakim stopniu naród oddalił się od swoich konstytutywnych cech. Przywoływano tu całe dzieje narodowe, ale równocześnie mając za punkt odniesienia zupełnie świeże wydarzenia: rok $1806 \mathrm{w}$ zaborze

${ }^{88}$ Diariusz 1818, t. 2, s. 8.

${ }^{89}$ J. Polaczek, Sztuka i polityka w Księstwie Warszawskim. Dzieje, formy, treść i dziedzictwo, Rzeszów 2005, s. 248, il. 201-202; S. Cierpisz, „Apoteoza Aukcji Wojska”. Nieznany rysunek Franciszka Smuglewicza, „Wiek Oświecenia” 32, 2016, s. 123-124. 
pruskim i 1809 w Galicji. To wtedy podstawowe wartości wspólnoty waleczność i ofiarność - miały powrócić w pełnym blasku i stać się powszechnym doświadczeniem. W $1818 \mathrm{r}$. odrodzenie ducha rycerskiego funkcjonowało już nie jako postulat, ale coś, co dopełniło się w Księstwie Warszawskim $^{90}$. Zauważmy, że taka wizja przeszłości i teraźniejszości narodu, wiążąca ziemiańskie zachowania w sferze publicznej z trwaniem wspólnoty, pozbawiała dziejowego znaczenia inne grupy czy warstwy społeczne i deprecjonowała inne formy uczestnictwa w życiu zbiorowości.

W debacie sejmowej w 1818 r. pojawiała się charakterystyczna alegoria składania ofiar na ołtarzu ojczyzny. Odnosiła się ona do czasów Księstwa Warszawskiego. Ziemianie, mówił Onufry Małachowski, „nawet w chwilach niepewnej wróżby przyszłych nadziei, znosili na ołtarz ojczyzny zapasy domowych dostatków, które chociaż natłokiem krytycznych czasów wyczerpane zostały, nie ostudziły wytrwałych poświęceń". Ta ofiarność to „duch szlachetności narodowej”, szczególnie cechujący „obywateli ziemianów”. Natomiast kapitaliści „nie stawali ani w dobrej, ni w złej przygodzie przy ołtarzu ofiary" ${ }^{91}$. Franciszek Obniski mówił, że ziemianin „w imię ojczyzny ostatnie niósł na jej ołtarz zasiłki”"22, a Stanisław Pieniążek wspominał, że „chętnie nasze majątki złożyliśmy na ołtarzu ojczyzny" 93 . Ten ołtarz ojczyzny to obraz bardzo charakterystyczny dla piśmiennictwa czasów Księstwa Warszawskiego. Dawny referendarz wielki koronny Jan Małachowski, wzywając w grudniu 1806 r. do dobrowolnych ofiar na potrzeby ojczyzny, pisał: „Oto wznosi się w pośrodku was z okropnych gruzów i rozwalin święty ołtarz ojczyzny. Ołtarz bez ofiary byłby obelgą tak świętego imienia" 94 . I przez cały czas Księstwa Warszawskiego czytamy o obywatelach składających dary na tym ołtarzu - w postaci dobrowolnych ofiar, podatków, własnych synów wysyłanych do wojska czy też publikacji w ważnych dla narodu kwestiach ${ }^{95}$. Ołtarz ojczyzny był też przedstawiany na okolicznościowych

90 Warto zwrócić uwagę, że odgrywający tak dużą rolę w debacie o moratorium generał Krasiński dobrze się nadawał na uosobienie tego odrodzenia ducha rycerskiego, tak przez tradycje rodowe, jak i własną wojskową biografię. Rola odegrana przez niego w tych debatach sejmowych jest interesująca również ze względu na często podkreślany wpływ „rycerskiej” ideologii domu rodzinnego na jego syna Zygmunta (zob. M. Janion, Zygmunt Krasiński - debiut i dojrzałość, Warszawa 1962, s. 16-21).

${ }^{91}$ Diariusz 1818, t. 2, s. 9.

92 Ibidem, s. 11.

93 Ibidem, s. 20.

94 „Gazeta Warszawska” 9 XII 1806, 98 dodatek, s. 1540.

95 Zob. np. Korespondencja w materiach obraz kraju i narodu polskiego rozjaśniających, Warszawa 1807, s. 75, 100, 175, 270; „Dziennik Konfederacji Generalnej Królestwa Polskiego" 19 VII 1812, 5, s. 39; 20 VII 1812, 6, s. 48; 10 VIII 1812, 7, s. 154; 20 VIII 1812, 22, 
transparentach, a nawet stawiany jako część dekoracji uroczystości narodowych $^{96}$. Z kolei w dyskusjach sejmowych obraz składania darów na ołtarzu ojczyzny pojawiał się, gdy mowa była o podatkach ${ }^{97}$. Wracanie do tej alegorii w $1818 \mathrm{r}$. jest znamienne nie tylko dlatego, że pokazuje trwanie pewnych wątków ideowych z czasów Księstwa Warszawskiego. Wydaje się też, że mamy tu pewien sposób myślenia o narodzie. Wspólnota narodowa odradza się w akcie wspólnej woli - gdy obywatele w krytycznym momencie zbiegają się do ołtarza ojczyzny, ofiarując siebie, swoje dzieci oraz pieniężne i rzeczowe dary. Kluczowa jest gotowość do ofiary, do wyjścia poza zwykłe zobowiązania obywatelskie, do narażenia życia i majątku.

Izba poselska w 1818 czy 1820 r., ze względu na swój skład, była idealnym miejscem do zbiorowego celebrowania tego mitu ziemiańsko-rycerskiego. Większość (około 80 proc.) stanowili w niej właśnie ziemianie - nie tylko posłowie, ale i deputowani wybrani na zgromadzeniach gminnych $^{98}$. W izbie poselskiej mówiono otwarcie, którą ze stron sporu o zadłużenie ziemiaństwa reprezentują jej członkowie. Krasiński, otwierając debatę w 1818 r., wspominał o „naszych ofiarach" na rzecz ojczyzny, ale zaznaczał: „cnota krajowa i nasz honor, chociaż więcej uciemiężonym, rządzić nam cudzą własnością nie pozwala” (czyli własnością wierzycieli); mówił też o konieczności zapewnienia „nieskażytelności naszych obietnic"99. Było to więc ustawienie i siebie, i izby po stronie ziemian dłużników. Poseł Oebschelwitz zwracał się do członków izby: „wy właściciele ziemi" ${ }^{100}$. Najmocniej mówił o tym przeciwny moratorium poseł Grabowski: „Uważajcie, że świat na was cały patrzy, jak swoją sprawę własną zadecydujecie. [--] Pomnijcie, że to nie z lichwiarzami, ani jak w głosach wielu przywiedzionych słyszę spekulantami, ale z wdowami,

s. 208; 24 VIII 1812, 24, s. 221; „Gazeta Warszawska” 6 XII 1806, 97, s. 1518; 19 XII 1806, 101, s. 1588; 18 IV 1807, 31, s. 480; 11 VII 1809, 55, s. 976; 29 VIII 1809, 69, s. 1259; „Gazeta Korrespondenta Warszawskiego i Zagranicznego" 13 VI 1809, 47 dodatek, s. 656.

96 "Gazeta Korrespondenta Warszawskiego i Zagranicznego" 6 II 1808, 11, s. 132; 22 VIII 1809, 67, s. 1005-1006; 9 IX 1809, 72, s. 1090; 8 IX 1812, 72, s. 1148.

${ }_{97} \mathrm{~J}$. Bojanowski, Odezwa posła powiatu wschowskiego do współczłonków sejmu 1811go roku, [b.m.r.], s. 8, 42, 44; M. Wodziński, Mowa jaśnie wielmożnego ... posła brzeskiego w senacie dnia 22 grudnia 1811 r. miana, [b.m.r.]; idem, Mowa jaśnie wielmożnego ... posła brzeskiego na sesji sejmowej dnia 17 grudnia 1811 roku miana, [b.m.r.], s. 2; „Gazeta Korrespondenta Warszawskiego i Zagranicznego" 14 XII 1811, 100 dodatek, s. 1557 (mowa marszałka izby poselskiej Stanisława Sołtyka).

${ }^{98}$ J. Skowronek, Skład społeczny i polityczny sejmów Księstwa Warszawskiego i Królestwa Polskiego, PH 52, 1961, 3, s. 476.

99 Diariusz 1818, t. 2, s. 1.

100 Ibidem, s. 11. 
sierotami i bez żadnego sposobu ludźmi w podkomornym siedzącymi, którzy wam ostatnie swe siedziby sprzedawszy, stali się waszymi wierzycielami, macie dziś sprawę i sami ją sądzicie?"101. Charakterystyczne, że niektórzy członkowie izby w 1818 i 1820 r. zaczynali mowy od informacji o swoim własnym zadłużeniu, co też można wiązać z przekonaniem o reprezentowaniu przez izbę jednej strony tego sporu ${ }^{102}$. Warto zauważyć, że na obu sejmach również wśród posłów i deputowanych przemawiających przeciw moratorium przeważali ziemianie. I nierzadko wysuwali argumenty odwołujące się do interesów tej warstwy (los ziemiańskich wdów i sierot, sytuacja ziemian - wierzycieli, złe skutki dla dóbr ziemskich wynikające z braku obiegu kapitałów) ${ }^{103}$. Dyskutantem, który wnosił tu inną perspektywę, był tylko deputowany Krysiński. Znany ekonomista, wywodzący się z rodziny frankistowskiej, reprezentujący warszawskie środowisko mieszczańskie, jako jedyny w izbie poselskiej podważał ziemiański monopol na zasługi i ofiary wojenne: „Toczyła się krew nie jednej tylko klasy, toczyła się krew polska, a w niej równy mają udział i ci, których pomyślny traf na wyniosłym w towarzystwie posadził punkcie, i ci, którzy, choć główną podporą, choć pierwszym bytu narodowego są warunkiem, najmniej może dobrodziejstw doznając, najobficiej krew swoją w obronie kraju przelewają"104.

Nikt nie negował faktu, że zniesienie moratorium musi doprowadzić do zmiany właścicieli części majątków. Czy jednak taka zmiana byłaby czymś negatywnym? W 1818 r. Onufry Małachowski przyznawał, że z punktu widzenia rządu powinno to być obojętne, bo „ta ziemia czy jednego, czy drugiego staje się dziedzictwem, zawsze równo do publicznych przykładać się musi ciężarów". Ale pytał czy

101 Ibidem, s. 16. Dwa lata później Grabowski przekonywał, że „gdy prawo moratoryjne jest sądem na wierzycieli, potrzeba przeto, aby do obrad takowych sami wyłącznie wchodzili wierzyciele" (Dziennik 1820, t. 1, s. 213).

102 Diariusz 1818, t. 2, s. 8 (W. Niemojowski), 9 (O. Małachowski), 10 (F. Obniski), 16 (J. Grabowski); Dziennik 1820, t. 1, s. 193 (S. Jezierski). Pośrednio polemizował z takimi deklaracjami Wincenty Krasiński: „reprezentanci narodu, od kraju wybrani i ufnością współobywateli zaszczyceni, mają prawo się spodziewać, że w oświadczonych swych zdaniach o własny interes nie będą posądzeni" (ibidem, s. 214).

103 Znamienną postacią był tu poseł węgrowski Józef Grabowski, jeden z bardziej wyrazistych przeciwników moratorium, który uchodził za człowieka starej daty i oryginała (L. Łętowski, Wspomnienia pamiętnikarskie, oprac. H. Barycz, Wrocław 1952, s. 122; P. Lelewel, Pamiętniki i diariusz domu naszego, oprac. J. Lelewel-Friemannowa, Wrocław 1966, s. 258). W jego mowie, odwołującej się do „doskonałych uwag” Dominika Krysińskiego, pojawia się mocno archaiczna w 1818 r. deklaracja: „na żadne moratorium z miejsca mego nie pozwalam" (Diariusz 1818, t. 2, s. 16).

${ }^{104}$ Diariusz 1818, t. 2, s. 15. 
ten rodzaj dziedziców uformowany z egoistów i lichwiarzy, szczycąc się posiadłością ziemi, poszczyci się wytrwałą skwapliwością poświęceń i ofiar już w krytycznych chwilach doświadczonych przez dzisiejszych właścicieli. Czy ten duch narodowości, który nas godnymi czyni swobód naszych, będzie znamieniem kiedyś ludzi, co szczęście na prywatnych ograniczając widokach, nie stawali ani w dobrej, ni w złej przygodzie przy ołtarzu ofiary ${ }^{105}$.

W 1820 r. wątek ten wprowadził Samuel Bogumił Linde, znany raczej z zachowań koniunkturalnych, a tu rzucający wyzwanie większości izby. W diariuszu tak streszczono jego wypowiedź: „Obojętną zaś rzeczą być sądził, czy majątek jednego będzie w ręku drugiej lub innej trzeciej osoby, albo wreszcie cudzoziemca, lecz nieobojętną, gdy znajduje się w ręku niepewnych, gdy jest pod kredą; w tym bowiem razie naród szkoduje, bo majątek zostaje w ostatnim zaniedbaniu, podatki nie opłacają się, a strata prywatna staje się publiczną"106. Podobnie mówił deputowany Benedykt Kapica $^{107}$. Natomiast poseł hrubieszowski Antoni Ratomski polemizował z Lindem, twierdząc, że nie jest obojętne, kto jest właścicielem ziemi, zwłaszcza w kraju konstytucyjnym, „takim, którego potęga wewnętrzna, jak i rządu, nie na położeniu geograficznym, tak mało awantażownym, lecz na duchu jedności, przywiązaniu do panującego i wspólnej dążności zależy"108. Zamykając debatę, polemikę z Lindem podjął marszałek Rembieliński. Przyznawał, że z punktu widzenia ekonomii politycznej przechodzenie dóbr od zadłużonych ziemian w ręce kapitalistów jest korzystne, ale „pod względem narodowości i zamiłowania kraju wyzucie familiów polskich z dziedzin, których część na obronę ojczyzny poświęcili, gdy tamci gromadzili zbiory, obojętnym być nie może"109. Zauważmy, że nikt nie formułuje tu postulatu ograniczenia prawa posiadania dóbr ziemskich do potomków rycerskich „naddziadów”. Ale równocześnie posiadanie ich przez inne osoby jest przedstawiane jako swego rodzaju skandal moralny.

Niektórzy dyskutanci, poczynając od reprezentującego rząd w $1818 \mathrm{r}$. Szaniawskiego, przedstawiali proces tej zmiany właścicieli jako przebiegający w dwóch fazach. Najpierw majątki ziemiańskie miały być zajmowane przez bezwzględnych wierzycieli. Zwracano uwagę, że w przypadku zniesienia moratorium nastąpiłoby masowe sprzedawanie zadłużonych dóbr ziemskich i cena ziemi bardzo by spadła. A to z kolei, przy

\footnotetext{
105 Ibidem, s. 9.

106 Dziennik 1820, t. 1, s. 219.

107 Ibidem, s. 222.

108 Ibidem, s. 232.

109 Ibidem, s. 239.
} 
obowiązującej zasadzie spłacania długów według kolejności ich wpisu do księgi hipotecznej, oznaczałoby, że duża część wierzycieli w ogóle nie zostałaby spłacona. Szaniawski przewidywał, że „w tym ciągłym łańcuchu spólnego nieszczęścia" zrujnowani zostaliby dłużnicy, większość wierzycieli, a także osoby powiązane finansowo z jednymi i drugimi. W drugiej fazie, na skutek licznych procesów między dłużnikami a wierzycielami i między samymi wierzycielami, majątki byłyby przejmowane przez prawników. I to na koniec ci prawni krętacze, a nie kapitaliści mieli zastąpić potomków obrońców kraju: „cała z tylu szkód majątkowych i moralnych pociecha zostanie się [--] dla obrotniejszych prawników, dla sądowych oficjalistów egzekwujących, dla sekwestratorów i dla pewnego rodzaju ludzi, co w publicznych nieszczęściach umieją bezprawne ciągnąć korzyści”110. A marszałek Krasiński ostrzegał: „Na gruzach familii w kraju zasłużonych, na połowie majątku dłużników, wzniesie się nowy rząd pieniaczów, co zyskując z miliona procesów, i dawnych posiadaczów, i samychże wraz wierzycieli zniszczą"111. Oczywiście, wygodniej było tak przedstawiać istotę sporu, bo moratorium stawało się w takim ujęciu sposobem na ochronę nie tylko dłużników, ale i wierzycieli. Ale znów - lęk przed zawodowymi prawnikami jako ekspansywną grupą dążącą do zajęcia miejsca ziemiaństwa był obecny w dyskusjach z czasów Księstwa Warszawskiego.

Wielcy dostawcy wojskowi, których zwolennicy moratorium tak chętnie ukazywali wśród wierzycieli, byli w większości Żydami ${ }^{112}$. Jednak słowo „Żyd” ani razu nie pojawia się w zapisie tych dwóch dyskusji sejmowych w diariuszach. Oczywiście nie wiemy, czy nie padło podczas posiedzenia. Można jednak założyć, że gdyby w dyskusji na większą skalę utożsamiano kapitalistów z Żydami, pozostawiłoby to jakieś ślady w diariuszach. Jak można wytłumaczyć wytłumienie tego wątku (zwłaszcza że były to lata bardzo intensywnej publicystycznej dyskusji o kwestii żydowskiej)? Być może nie chciano mieszać tych dwóch debat, sprowadzać kwestii moratorium do kwestii żydowskiej. Możliwe też, że obawa przed odebraniem wypowiedzi jako obrony własnego czy środowiskowego interesu mogła powstrzymywać przed atakami na konkretne grupy społeczne czy wyznaniowe. Wygodniej było w tej sytuacji tworzyć bardziej modelowe, abstrakcyjne obrazy konfliktu wokół moratorium. Wątek wykupywania dóbr przez Żydów pojawił się natomiast

110 Diariusz 1818, t. 2, s. 4.

111 Ibidem, s. 1.

112 J. Kosim, Losy pewnej fortuny. Z dziejów burżuazji warszawskiej w latach 1807-1830, Wrocław 1972, s. 54-87. 
w polemikach prasowych. Anonimowy autor postulował pozwolenie im na kupowanie dóbr ziemskich, pytając „,czyli w oczach statystyki nie wszystko jedno, kto tę lub inną wieś posiada, byle korzystnie dla kraju ekonomikę prowadził i podatki wypłacał"113. Jego oponent twierdził, że Żyd, który „w samych tylko zyskach pieniężnych szuka wspólności z innymi", nie będzie ani dobrym gospodarzem, ani prawdziwym obywatelem.

Wykupiwszy autor dawnych obywateli przez Żydów, czyliż z nich będzie wybierał na sędziów, na prawodawców? Czy w potrzebie kraju szukać będzie pomiędzy nimi Zamoyskich, Czarnieckich, Kościuszków itp.? Nie, nigdy Żyd nie będzie rolnikiem, bo nie lubi ani pracy, ani ochędóstwa. [--] Równie nie będzie nigdy Żyd obrońcą kraju, bo jest tchórzem, interesem lichwiarskim powodowany, bez ambicji; nie zna czucia dla ojczyzny, prócz urojonej ziemi ${ }^{114}$.

Warto zauważyć, że prawo obowiązujące w Królestwie nie pozwalało Żydom na kupowanie dóbr ziemskich ${ }^{115}$. Znów mamy tu do czynienia z lękami sięgającymi dalej w przyszłość, z wyobrażaniem sobie dłuższej sekwencji wydarzeń.

Nawiasem mówiąc, wydaje się, że spór o moratorium jest ważnym, a słabo dostrzeganym kontekstem ówczesnej debaty o kwestii żydowskiej. Intensywność tej debaty w pierwszych latach Królestwa Polskiego wynikała, jak sądzę, nie tylko z prac legislacyjnych i działań administracji państwowej wobec Żydów. Istotne było też poczucie zagrożenia pozycji społecznej ziemiaństwa. Dobrym przykładem jest tu „Moszkopolis” Juliana Ursyna Niemcewicza, obraz Warszawy w roku 3333 jako miasta żydowskiego. Słusznie Maria Janion podkreśla, że ta antyżydowska satyra zapowiadała „bardzo niebezpieczny polski fantazmat antysemicki o Polsce przerobionej przez Żydów na Judeo-Polonię"; stąd wznawianie i szerokie kolportowanie tego tekstu na przełomie XIX i XX w. ${ }^{116} \mathrm{Gubi}$ się tu jednak kontekst początku XIX w. Narrator tej opowieści dowiaduje się ze zgrozą, że wiozący go dorożkarz nazywa się Zamoyski. Ten opowiada, że w opanowanej przez Żydów Warszawie „Radziwiłłowie są malarzami, Potoccy i Sanguszkowie bawią się furmanką i drzewo wożą od Wisły, Chodkiewicze, Krasińscy, Lubomirscy, Sapiehy poszli na

113 J.K., Uwagi nad upadkiem kredytu, s. 1040.

114 Odpowiedź na uwagi względem upadku kredytu, 16 VI 1821, 96, s. 1212.

115 A. Eisenbach, Emancypacja Żydów na ziemiach polskich 1785-1870 na tle europejskim, Warszawa 1988, s. 244-246.

${ }^{116}$ M. Janion, Do Europy tak, ale razem z naszymi umarłymi, Warszawa 2000, s. 123-124. 
cieślów". Wilanów należy do Icka Szmulowicza, zamiast dawnego ogrodu są tam „wielka gorzelnia, browar i wołownia”"117. Ta zmiana właścicieli ziemskich dokonywała się stopniowo, wyjaśnia narratorowi spotkany żydowski mecenas; po tym, jak pozwolono Żydom nabywać dobra ziemskie, wkrótce „najpiękniejsze majątki” były w rękach żydowskich ${ }^{118}$. To ten sam lęk przed wielkim przewrotem własnościowym, który mamy w dyskusji o moratorium.

Ksiądz Łętowski pisał w swojej broszurze: „Jeżeli taki przelew majątków jest w porządku kolei losów, o biada krajowi! ... gdzieby Cincinatusowe cnoty tułały się wśród nowego pokolenia urągań"119. Rewolucja własnościowa to dla zwolenników moratorium koniec narodu. I to koniec narodu, który może nastąpić przy zachowaniu pozorów jego dalszego trwania. Pojawia się tu bowiem wizja „pustej”, pozornej wspólnoty politycznej, składającej się z nowych obywateli, płacących podatki, dobrze gospodarujących, ale nieskłonnych niczego poświęcić dla przetrwania tej wspólnoty. Obywateli, którzy nie odtwarzają (i nie mogą odtwarzać) zachowań ofiarnych przodków. Byłaby to wspólnota oparta na teorii prawa czy na naukach ekonomii politycznej, ale pozbawiona najważniejszego - woli przetrwania. Są tu jakby dwa rodzaje obywatelstwa - formalne i rzeczywiste, to drugie wiążące się z ofiarnością na cele narodowe. Formalne, wynikające jedynie z przepisów prawa obywatelstwo jest dwuznaczne moralnie, bo daje pełne prawo do uczestniczenia w życiu narodu bez poświęceń dla niego i - co więcej - wykorzystując cudze poświęcenia. Warto zauważyć, że w przypadku obu rodzajów obywatelstwa przywoływane jest płacenie podatków. Gdy mówi się o ofiarach na rzecz ojczyzny podatki też stają się przykładem takiej ofiarności. W innym kontekście płacenie podatków to jakby wyznacznik pozornego obywatelstwa, coś, co ma zastąpić prawdziwe zaangażowanie na rzecz wspólnoty.

Wspólnota narodowa jest tu widziana w kontekście bytu politycznego, państwowego; naród to zbiorowość obywateli, uczestniczących w życiu państwa lub dążących do jego odzyskania. Centralne znaczenie ma element wolicjonalny - naród istnieje przede wszystkim dzięki woli swoich prawdziwych obywateli, dzięki ich ofiarności i waleczności. Przy czym istotna jest tu sama wola odzyskania i utrzymania wspólnoty politycznej, a nie jej forma ustrojowa, specyficzne instytucje i prawa. Zauważmy, że przesunięcie punktu ciężkości z faktu istnienia wspólnoty

117 J.U. Niemcewicz, Rok 3333, czyli sen niesłychany, „Przegląd Poznański” 26, 1858, s. 348-349.

118 Ibidem, s. 352.

119 L. Łętowski, O moratorium, s. 15. 
politycznej na wolę jej posiadania było przejawem stopniowego tworzenia się języka politycznego, w którym można opisać trwanie narodu bez państwa.

Naród, jak pisałem, to w tej dyskusji zasadniczo zbiorowość większych właścicieli - ziemian, mieszczan, „kapitalistów”. Poza Krysińskim nikt nie mówił o narodzie w znaczeniu wszystkich mieszkańców kraju. Można sądzić, że wynika to z kontekstu dyskusji - chodziło wszak o rozliczenia między właścicielami ziemi i kapitału. Zapewne wielu uczestników tej dyskusji, pisząc czy mówiąc o narodzie w innym kontekście (np. wypowiadając się o charakterze narodowym Polaków), używałoby tego słowa w szerszym społecznie znaczeniu. Taka chwiejność terminologiczna, używanie pojęcia „naród” w znaczeniu tradycyjnym i w nowoczesnym przez te same osoby, nawet w jednym tekście, jest charakterystyczna dla wielu intelektualistów tej epoki ${ }^{120}$. Ale sam fakt, że tak łatwo można było poprzestać na znaczeniu tradycyjnym, wydaje się znaczący.

Jak pisałem, dyskusja nad moratorium jest interesująca również ze względu na kształtowanie się polskiej myśli konserwatywnej. Można tu wskazać kilka wątków o wyraźnie konserwatywnym charakterze. Jest to przede wszystkim opozycja wobec wspólnot odwołujących się nie do tradycji, ale konstruowanych w oparciu o racjonalne przesłanki, konstytuowanych przez prawo lub przez reguły ekonomii. Ład zakorzeniony w tradycji, odwieczny i organiczny, przeciwstawiony jest abstrakcyjnym projektom społeczeństwa, odwołującym się do oświeceniowych koncepcji natury ludzkiej; prawdziwy patriotyzm - formalnemu obywatelstwu (które okazuje się destrukcyjnym dla wspólnoty egoizmem). Odbudowa wspólnoty wiąże się z powrotem do tradycyjnych, dziedziczonych cnót, do odtwarzanych przez kolejne pokolenia postaw i zachowań w sprawach publicznych. Znamienny jest też pesymizm co do możliwości powielania tych postaw i zachowań przez ludzi nowych, niefunkcjonujących od dzieciństwa w kręgu tradycji. Mamy tu tak charakterystyczne dla myśli konserwatywnej przekonanie o istnieniu i o kluczowej roli warstwy historycznej uosabiającej tradycyjne wartości i ducha narodu. Warstwy, której początki giną w pomroce dziejów, tak jak w tej pomroce giną początki narodu. Konserwatywny jest też strach przed nagłym załamaniem tradycyjnego ładu, będącego nośnikiem konstytutywnych dla wspólnoty cnót i przekonań oraz lęk przed chaosem, w którym nawet

120 A. Wierzbicki, Spory o polska duszę. Z zagadnień charakterologii narodowej $w$ historiografii polskiej XIX i XX w., Warszawa 1993, s. 42-47, 66-70; M. Janowski, Rozpacz oświeconych? Przemiana polskiego języka politycznego a reakcje na upadek Rzeczypospolitej, „Wiek Oświecenia” 25, 2009, s. 40-45; M. Mycielski, „Miasto ma mieszkańców, s. 260-261. 
pozorni beneficjenci wielkiej zmiany (w tym przypadku wierzyciele) na koniec okażą się jej ofiarami.

Oczywiście, można zapytać, czy nie mamy tu do czynienia po prostu z tradycjonalizmem. W końcu wiele z tych wątków było obecnych w myśleniu szlachty od kilku stuleci, a w omawianej dyskusji były one użyte do obrony trwającej również od stuleci rzeczywistości społecznej. I tak np. posłużenie się argumentami dawności i obrony dokonań przodków to nawiązanie do bardzo starego sposobu myślenia, ciągle powracającego w polskim myśleniu politycznym od XVI do XVIII w. ${ }^{121}$ Czy zatem nie przeceniamy dyskusji o moratorium, dopatrując się w niej konstruktów ideowych typowych dla ideologii konserwatywnej początku XIX w.? Dość powszechnie przyjmuje się, że konserwatyzm jako ideologia (a nie odruchowa postawa czy predyspozycja psychiczna) jest efektem załamania się na przełomie XVIII i XIX w. tradycyjnego ładu oraz powstania sytuacji, w której zwykły tradycjonalizm nie mógł już być odpowiedzią na zmiany ze względu na ich skalę i nieodwracalność. Konserwatyści stanęli wobec niemożliwości przywrócenia dawnego świata, starali się jednak zaszczepić w nowej rzeczywistości to, co uznawali za odwieczne podstawy ładu. Siłą rzeczy oznaczało to konieczność „wymyślenia tradycji”, wyboru pewnych elementów z przeszłości jako kluczowych dla społecznego i politycznego porządku. Była to sytuacja obrony tradycyjnych podstaw wspólnoty w świecie, który dramatycznie się przekształcił, w świecie racjonalizmu i indywidualizmu. Konserwatyści formułowali swoje postulaty ze świadomością, że są one sprzeczne z „duchem epoki”, $z$ rozpowszechnionym sposobem myślenia ${ }^{122}$.

Gdzie w polskiej myśli politycznej tej epoki można znaleźć analogiczne dylematy i podobny styl myślenia? Wskazałbym tu na konstrukt ideowy „wskrzeszonej Polski”, który tworzył ramy dla debaty ideowej w Księstwie Warszawskim, a w niemałym stopniu też w Królestwie Polskim; był także podstawowym kontekstem ideowym dyskusji o moratorium ${ }^{123}$. Pisząc o tym wskrzeszeniu ojczyzny w najróżniejszych tekstach - od rozpraw do patriotycznych rymowanek - rzadko przedstawiano je jako powrót do stanu sprzed upadku Rzeczypospolitej (nawet w wersji trzeciomajowej). Wspólnota polityczna miała się konstytuować

${ }^{121}$ Zob. A. Grześkowiak-Krwawicz, Dyskurs polityczny Rzeczypospolitej Obojga Narodów. Pojęcia i idee, Toruń 2018, s. 337-376.

122 Zob. np. J. Szacki, Tradycja, Warszawa 2011, s. 189-204.

${ }^{123}$ Brakuje opracowania ukazującego syntetycznie refleksję o „wskrzeszeniu ojczyzny" w Księstwie Warszawskim i Królestwie Polskim; dużo materiału przynoszą natomiast studia szczegółowe. Dla sztuk plastycznych interesujące ustalenia: M. Getka-Kenig, Pomniki publiczne i dyskurs zasługi w dobie „wskrzeszonej” Polski lat 1807-1830, Kraków 2017. 
na nowo przez odrodzenie „ducha narodowego”. Ten ostatni mógł być różnie rozumiany, ale ważny jest tu sam mechanizm sięgania do „pierwszej zasady" czy konstytutywnych cech narodu, a nie do pamiętanych lub znanych z opowiadań realiów przedrozbiorowych. Przeważnie w poszukiwaniu tego „ducha narodu” cofano się do XVII w. lub wcześniej, przerzucając pomost nad XVIII stuleciem, oczywiście z wyjątkiem Sejmu Czteroletniego i insurekcji, które postrzegane były jako początek odrodzenia. Ważny był też wątek rycerski, odnoszący się do szlachty, ale znów raczej do heroicznej epoki wielkich wodzów, a nie do stanu szlacheckiego z XVIII w. Oczywiście, konstrukt ideowy „wskrzeszonej Polski” nie był sam w sobie konserwatywny - przy odpowiedniej interpretacji narodowej historii mógł stanowić ramy dla najróżniejszych nurtów politycznych. Ale charakterystyczny dla niego sposób sięgania do przeszłości, w połączeniu z obroną stanu posiadania ziemiaństwa, tworzył podobne schematy myślowe, jakie znajdziemy w zachodnioeuropejskiej myśli konserwatywnej. W omawianej tu dyskusji zwolennicy moratorium widzieli naród jako - by posłużyć się określeniem Jerzego Szackiego „wspólnotę historycznie daną"124, posiadającą specyficzne, odwieczne cechy, a trwanie narodu wiązali z odtwarzaniem zachowań „naddziadów”. Ale równocześnie widać poszukiwanie „pierwszej zasady” wspólnoty politycznej, czytelna jest świadomość, że przedrozbiorowe społeczeństwo stanowe bezpowrotnie przeminęło, a także poczucie, że „duch narodowy", który może zapewnić trwanie tej wspólnoty, jest w zasadniczym konflikcie ze współczesnym światem. Oczywiście, nie mamy tu do czynienia z jakąś spójną doktryną czy ideologią (może z wyjątkiem koncepcji Szaniawskiego). Ale błędem byłoby, moim zdaniem, widzieć tu tylko tradycjonalistyczne odruchy czy prostą kontynuację sarmackiego myślenia politycznego.

Warto zauważyć, że ten konserwatyzm ma jednak wyraźny rys republikański. Ciągłość trwania narodu zależna jest od cnót politycznych obywateli. Gromadzą się oni nie wokół monarchy, tradycyjnych instytucji, Kościoła, wiary, ale w wyniku spontanicznej mobilizacji na wezwanie ojczyzny. Dobrze to oddaje wspomniana alegoria ołtarza ojczyzny.

Jak prezentowane w tej dyskusji poglądy mogły się przekładać na postawy polityczne w Królestwie Polskim i w czasie powstania listopadowego? Lęk przed społecznym przewrotem mógł uzasadniać zachowania skrajnie lojalistyczne, jak w przypadku tak aktywnego w tej dyskusji Wincentego Krasińskiego. Ale w tym, co mówili i pisali zwolennicy

${ }^{124}$ J. Szacki, Ojczyzna, naród, rewolucja. Problematyka narodowa w polskiej myśli szlacheckorewolucyjnej, Warszawa 1962, s. 12. 
moratorium, przywołując patriotyczny entuzjazm i ofiarność z czasów Księstwa Warszawskiego, widać przekonanie, że Polacy będą w przyszłości przechodzili przez podobne próby - a więc znów dojdzie do walki o sam byt narodu i do sytuacji, w której będzie potrzebna ofiarność daleko wychodząca poza zwykłe obowiązki obywatela. Jak się to miało do geopolitycznej sytuacji Królestwa Polskiego? Z kim miałaby się toczyć walka o byt narodu? Tego się oczywiście nie dowiemy z tych dyskusji, ale można tu widzieć uznawanie sytuacji politycznej Królestwa za stan, w dłuższej perspektywie, przejściowy.

\section{Streszczenie}

Artykuł omawia dyskusję nad moratorium na spłatę zadłużenia dóbr ziemskich w Królestwie Polskim, która toczyła się na dwóch sejmach, w 1818 i 1820 r., a także w prasie. Kwestia ta była okazją do szerszej dyskusji o wspólnocie narodowej, postawach obywatelskich, o politycznej roli różnych grup społecznych. Zwolennicy moratorium uważali długi za skutek zniszczeń wojennych i ofiarności ziemian na cele narodowe w czasach Księstwa Warszawskiego. Ofiarnym ziemianom przeciwstawiali „kapitalistów” czyli właścicieli kapitału, którzy mieli nie ucierpieć wskutek wojen i zachowywać się obojętnie wobec sprawy narodowej. Przeciwnicy moratorium twierdzili, że zadłużenie pochodzi głównie sprzed 1806 r. i jest efektem złego gospodarowania i luksusowej konsumpcji, a istnienie „kapitalistów” jako osobnej grupy społecznej w ogóle negowali. Dominujący w tej debacie zwolennicy moratorium obawiali się powszechnego przejęcia dóbr ziemskich przez właścicieli kapitału, a także obrotnych prawników. Miałby to być koniec wspólnoty narodowej, gdyż to dawne rody właścicieli ziemskich od pokoleń miały swoją ofiarnością podtrzymywać istnienie tej wspólnoty. Definiowanie narodu przez jego cechy historyczne, wizja odtwarzania przez ziemian-rycerzy konstytutywnych dla wspólnoty narodowej postaw i zachowań oraz lęk przed załamaniem się odwiecznego ładu pozwalają uznać, że mamy tu do czynienia z myślą konserwatywną.

\section{Landowners' Debts and a National Community. A Debate over the Moratorium on Debtors in the Kingdom of Poland in 1815-25}

The article presents the debate over the moratorium on the repayments of landowners' debts which was held in the Kingdom of Poland in two Sejm sessions, in 1818 and 1820, and in the press. The question of the moratorium was an opportunity for a broader discussion on the national community, civic attitudes, political roles of various social groups. The supporters of the moratorium regarded the indebtedness of landed estates as the result of war damage and heavy 
sacrifices made by the landed nobility for national purposes in the era of the Duchy of Warsaw (1807-15). They contrasted 'generous' landlords with egoistic 'capitalists', that is owners of capital who had not suffered wartime losses and remained indifferent to the national cause. The moratorium's opponents argued that debts had been incurred before 1806 as the result of mismanagement and luxury consumption while denying the existence of 'capitalists' as a social group. The supporters, who dominated the debate, feared both a widespread takeover of landed estates by 'capitalists' and grasping lawyers. This would be the end of the national community, for it had been the generosity of long generations of landowners that maintained the existence of that community. Defining the nation by its historical features, the vision of performing by landowners-knights attitudes and behaviours constitutive for the national community, and fear of the collapse of the old-established social order allow us to assume that conservative thought proved decisive.

\section{Bibliografia}

Bojanowski J., Odezwa posła powiatu wschowskiego do współczłonków sejmu 1811go roku, [b.m.r.].

Cierpisz Szymon, „Apoteoza Aukcji Wojska”. Nieznany rysunek Franciszka Smuglewicza, „Wiek Oświecenia” 32, 2016, s. 109-126.

Czermiński Florian, o Towarzystwie Kredytowym Ziemskim w Królestwie Polskim, [s.n.], Warszawa 1866.

Czubaty Jarosław, Księstwo Warszawskie (1807-1815), Wydawnictwa UW, Warszawa 2011.

Czubaty Jarosław, Zasada „dwóch sumień”. Normy postępowania i granice kompromisu politycznego Polaków w sytuacjach wyboru (1795-1815), Neriton, Warszawa 2005.

Czy są i jakie sposoby ratowania naszych dłużników, „Rozmaitości” nr 31 (dodatek do „Gazety Korrespondenta Warszawskiego i Zagranicznego”) 30 IX 1820, 130, s. $115-119$.

Diariusz sejmu Królestwa Polskiego 1818, t. 2, nakł. N. Glücksberga, Warszawa 1818.

Dziennik posiedzeń izby poselskiej w czasie sejmu Królestwa Polskiego w roku 1820 odbytego, w Drukarni Xięży Piiarów, Warszawa 1820.

„Dziennik Praw” [Królestwa Polskiego] 3, 1817, 15.

Eisenbach Artur, Emancypacja Żydów na ziemiach polskich 1785-1870 na tle europejskim, PIW, Warszawa 1988.

Gąsiorowska Natalia, Wolność druku w Królestwie Kongresowym 1815-1830, Skład główny w Księgarni Gebethnera i Wolffa, Warszawa 1916.

Getka-Kenig Mikołaj, Pomniki publiczne i dyskurs zasługi w dobie „wskrzeszonej” Polski lat 1807-1830, Universitas, Kraków 2017.

Grabowski Józef, Głos jaśnie wielmożnego ... posła województwa podlaskiego z powiatu węgrowskiego miany na sesji sejmowej dnia 12 kwietnia 1818 roku, [b.m.r.].

Grześkowiak-Krwawicz Anna, Dyskurs polityczny Rzeczypospolitej Obojga Narodów. Pojęcia i idee, Wydawnictwo Naukowe UMK, Toruń 2018. 
J.K., Uwagi nad kapitalistami i szkodliwymi skutkami lichwy, „Rozmaitości Warszawskie” (dodatek do „Gazety Korrespondenta Warszawskiego i Zagranicznego”), 11 V 1825,19 , s. $148-150$.

J.K., Uwagi nad upadkiem kredytu w kraju i nad środkami zapobiegającymi niedostatkowi w nim pieniędzy, „Gazeta Korrespondenta Warszawskiego i Zagranicznego” $22 \mathrm{~V}$ 1821,82 , s. $1038-1041$.

Janion Maria, Do Europy tak, ale razem z naszymi umarłymi, Sic!, Warszawa 2000.

Janion Maria, Zygmunt Krasiński - debiut i dojrzałość, Wiedza Powszechna, Warszawa 1962.

Janowski Maciej, Rozpacz oświeconych? Przemiana polskiego języka politycznego a reakcje na upadek Rzeczypospolitej, „Wiek Oświecenia” 25, 2009, s. 29-60.

Jasiukowicz Stanisław, Zarys dziejów powstania Towarzystwa Kredytowego Ziemskiego, „Przegląd Narodowy” 4, 1911, 8, s. 121-156; 9, s. 250-284.

Kizwalter Tomasz, 0 nowoczesności narodu. Przypadek polski, Semper, Warszawa 1999.

Korespondencja w materiach obraz kraju i narodu polskiego rozjaśniających, Drukarnia Gazety Warszawskiey, Warszawa 1807.

Kosim Jan, Losy pewnej fortuny. Z dziejów burżuazji warszawskiej w latach 1807-1830, Ossolineum, Wrocław 1972.

Król Marcin, Konserwatyści a niepodległość. Studia nad polska myśla konserwatywna XIX wieku, Pax, Warszawa 1985.

Lelewel Prot, Pamiętniki i diariusz domu naszego, oprac. Irena Lelewel-Friemannowa, Ossolineum, Wrocław 1966.

Lubecki Franciszek Ksawery, Mowa jaśnie oświeconego księcia ... ministra przychodów i skarbu, miana w izbie poselskiej na posiedzeniu dnia 21 maja 1825 roku przy wniesieniu projektu do prawa o Towarzystwie Kredytowym Ziemskim, [b.r.m.w.].

Łętowski Ludwik, o moratorium czyli dwa sposoby uiszczenia się wierzycielom, w Drukarni Wiktora Dąbrowskiego Sukcessorów, Warszawa 1816.

Łętowski Ludwik, Wspomnienia pamiętnikarskie, oprac. Henryk Barycz, Ossolineum, Wrocław 1952.

Mycielski Maciej, „Miasto ma mieszkańców, wieś obywateli”. Kajetana Koźmiana koncepcje wspólnoty politycznej (do 1830 roku), Wydawnictwo Naukowe UMK, Toruń 2017.

Mycielski Maciej, Między izba a cesarzem. Marszałkowie izby poselskiej w Królestwie Polskim, „Przegląd Historyczny” 84, 1993, s. 135-150.

Mycielski Maciej, Rząd Królestwa Polskiego wobec sejmików i zgromadzeń gminnych 1815-1830, Wydawnictwa UW, Warszawa 2010.

Myśli o upadku kredytu krajowego, „Gazeta Korrespondenta Warszawskiego i Zagranicznego" 4 VI 1821, 89, s. 1143-1145.

Niemcewicz Julian Ursyn, Rok 3333, czyli sen niestychany, „Przegląd Poznański” 26, 1858, s. 346-356.

Niemojowski Wincenty, Głosy posła kaliskiego na sejmie Królestwa Polskiego 1818, Poznań [b.d.w.].

Nowy słownik, „Pszczółka Krakowska” 12 XII 1819, 18, s. 200.

O moratorium, czyli dwa sposoby uiszczenia się wierzycielom, Warszawa 1816 [rec.], „Pamiętnik Warszawski” 7, 1817, styczeń, s. 103-105. 
Odpowiedź na uwagi względem upadku kredytu i onegoż polepszenia, „Gazeta Korrespondenta Warszawskiego i Zagranicznego" 15 VI 1821, 95, s. 1197-1198; 16 VI 1821, 96, s. 1211-1213.

Polaczek Janusz, Sztuka i polityka w Księstwie Warszawskim. Dzieje, formy, treść i dziedzictwo, Wydawnictwo Uniwersytetu Rzeszowskiego, Rzeszów 2005.

Potocki Stanisław Kostka, Świstek krytyczny, „Pamiętnik Warszawski” 7, 1817, luty, s. 249-272.

Skowronek Jerzy, Skład społeczny i polityczny sejmów Księstwa Warszawskiego i Królestwa Polskiego, „Przegląd Historyczny” 52, 1961, 3, s. 466-491.

Stankiewicz Zbigniew, Szlachta-ziemianie w świetle ankiety włościańskiej 1814 r., w: Ziemiaństwo polskie 1795-1945. Zbiór prac o dziejach warstwy i ludzi, red. Janina Leskiewiczowa, PWN, Warszawa 1985, s. 85-120.

[Stawiarski Ignacy], Uwagi nad moratorium, Warszawa 1816.

Szacki Jerzy, Ojczyzna, naród, rewolucja. Problematyka narodowa w polskiej myśli szlacheckorewolucyjnej, PIW, Warszawa 1962.

Szacki Jerzy, Tradycja, Wydawnictwa UW, Warszawa 2011.

Usurski Maciej, Udział Stanisława Staszica w pracach Rady Stanu Królestwa Polskiego, „Zeszyty Staszicowskie” 2006, 5, s. 89-165.

Wierzbicki Andrzej, Spory o polską duszę. Z zagadnień charakterologii narodowej w historiografii polskiej XIX i XX w., IH PAN, Warszawa 1993.

Wodziński Maciej, Mowa jaśnie wielmożnego ... posła brzeskiego na sesji sejmowej dnia 17 grudnia 1811 roku miana, [b.m.r.].

Wodziński Maciej, Mowa jaśnie wielmożnego ... posła brzeskiego w senacie dnia 22 grudnia 1811 r. miana, [b.m.r.].

Wójcikiewicz Włodzimierz, Prawo hipoteczne Królestwa Polskiego, Ossolineum, Wrocław 1967.

Wybicki Józef, Listy obywatelskie do Jana Węgleńskiego ministra Król. Polsk., „Pamiętnik Warszawski" 6, 1816, październik, s. 147-167; 6, 1816, listopad, s. 267-289; 7, 1817, marzec, s. 273-290.

Zieliński Andrzej, Naród i narodowość w polskiej literaturze i publicystyce lat 1815-1831, Ossolineum, Wrocław 1969.

Biogram: Maciej Mycielski, dr hab., pracuje na Wydziale Historii Uniwersytetu Warszawskiego. Zainteresowania badawcze: historia polityczna oraz historia myśli politycznej i społecznej pierwszej połowy XIX w.; kontakt: m.mycielski@uw.edu.pl.

Author: Maciej Mycielski, Dr hab., employed at the Faculty of History of the University of Warsaw. Research interests: political history, history of political and social thought of the first half of the nineteenth century. Contact: m.mycielski@ uw.edu.pl. 